\title{
Coagulation Abnormalities Due to COVID-19 in a Child with Thalassemia
}

\author{
Wulandewi Marhaeni ${ }^{1} \cdot$ Andreas Budi Wijaya $^{2} \cdot$ Khairiyadi $^{3} \cdot$ Munawaroh $^{4} \cdot$ Hendriyono $^{5}$
}

Received: 19 August 2020 / Accepted: 2 December 2020 / Published online: 8 January 2021

(C) Dr. K C Chaudhuri Foundation 2021

To the Editor: Novel coronavirus infection in Indonesia reached 140,000 cases by 17th August 2020. There was inadequate data that supported the involvement of coagulation problems in pediatric cases, especially those with transfusion-dependent-thalassemia.

We presented 4 pediatric cases of COVID-19 (positive oropharyngeal swab) and nonsplenectomized transfusiondependent-thalassemia (beta-thalassemia), which came for blood transfusion visit. Three patients were male and 1 patient was female. The age ranged from 9 y 8 -mo-old to 17 -y-old. All of our patients were mildly ill; mild respiratory symptoms were reported only in 2 cases; however, three patients showed lung infiltrate in the radiologic examination. None of them presented lymphopenia, thrombocytopenia, elevated CRP, elevated Troponin-T, or bleeding manifestation. The mean hemoglobin level was $6.7 \mathrm{~g} / \mathrm{dL}$. Elevated D-dimer was detected in 1 patient. Three thalassemic patients had prolongation of APTT or PT. None of our patients developed clinical thrombosis. The mean ferritin level $(2524.42 \mathrm{ng} / \mathrm{mL})$ has been

Wulandewi Marhaeni

wdmarhaeni@yahoo.com

1 Hematology-Oncology Division, Department of Pediatrics of Ulin General Hospital, Faculty of Medicine, Lambung Mangkurat University, Banjarmasin, South Kalimantan, Indonesia

2 Department of Pediatrics of Ulin General Hospital, Faculty of Medicine, Lambung Mangkurat University, Banjarmasin, South Kalimantan, Indonesia

3 Respirology Division, Department of Pediatrics of Ulin General Hospital, Faculty of Medicine, Lambung Mangkurat University, Banjarmasin, South Kalimantan, Indonesia

4 Department of Clinical Microbiology of Ulin General Hospital, Faculty of Medicine, Lambung Mangkurat University, Banjarmasin, South Kalimantan, Indonesia

5 Department of Clinical Pathology of Ulin General Hospital, Faculty of Medicine, Lambung Mangkurat University, Banjarmasin, South Kalimantan, Indonesia increased from the previous month (980.51-3672.63 ng/ $\mathrm{mL}$ ). Supportive and therapeutic care such as blood transfusion, antibiotics, antiviral were given. Oral iron chelator has still been given. Fibrinogen level, liver biopsy, and MRI T2* were not performed because of limitations.

Elevated D-dimer and PT prolongation have been reported in adult COVID-19, which might be related to worsening disease processes and poor prognosis [1,2]. Excessive activation of coagulation cascade will lead to D-dimer elevation and imbalance between procoagulant and anticoagulant homeostatic mechanisms [3]. Coagulation problems in adult thalassemia patients with COVID-19 suggested that it might not be more severe than the general population [4]. Appropriate to the previous study, our patients with thalassemia also showed less severity than the general population, which might suggest partial coagulation problems. The beta-thalassemia population should not have the same risk of COVID-19 as other patients, considering its reduced severity [5]. No recommendation for mildly ill patients to get prophylactic low molecular weight heparin. Dysregulation of the coagulation cascade is prominent findings in SARS-Cov-2 infection associated with transfusion-dependent-thalassemia. A larger sample is required to better understand the impact of coagulation abnormalities due to COVID-19 in beta-thalassemia children.

\section{Compliance with Ethical Standards}

Conflict of Interest None.

\section{References}

1. Loi M, Branchford B, Kim J, Self C, Nuss R. COVID-19 anticoagulation recommendations in children. Pediatr Blood Cancer. 2020;67:e28485.

2. Becker RC. COVID-19 associated coagulopathy. J Thromb Thrombolysis. 2020;50:54-67. https://doi.org/10.1007/s11239020-02134-3. 
3. Giannis D, Ziogas IA, Gianni P. Coagulation disorders in coronavirus infected patients: COVID-19, SARS-CoV-1, MERS-CoV and lessons from the past. J Clin Virol. 2020;127:e104362.

4. Taher AT, Bou-Fakhredin R, Kreidieh F, Motta I, de Franceschi L, Cappellini MD. Care of patients with hemoglobin disorders during the COVID-19 pandemic: an overview of recommendations. Am J Hematol. 2020;95(8):E208-10.
5. Marhaeni W, Wijaya AB, Kusumaningtyas P, Mapianto RS. Thalassemic child presenting with anosmia due to COVID-19. Indian J Pediatr. 2020;87:750. https://doi.org/10.1007/s12098-02003370-4.

Publisher's Note Springer Nature remains neutral with regard to jurisdictional claims in published maps and institutional affiliations. 